\title{
NOTES ON FOUR NEW AND NOTEWORTHY RECORDS OF LEJEUNEA FROM MEGHALAYA, INDIA
}

\author{
S. K. SingH ${ }^{1 *}$, T. Pócs ${ }^{2}$ and S. KumaR ${ }^{1}$ \\ ${ }^{1}$ Eastern Regional Centre, Botanical Survey of India, Shillong-793003, India \\ ${ }^{*}$ E-mail: sksbsinc@rediffmail.com \\ ${ }^{2}$ Department of Botany, Institute of Biology, Eszterházy Károly College \\ H-3301 Eger, Pf. 43, Hungary; E-mail: colura@upcmail.hu
}

(Received 24 June, 2015; Accepted 26 August, 2015)

Four species of Lejeunea viz., L. discreta, L. kashyapii, L. mehrana and L. parva are reported here for the first time from Meghalaya. Of which, Lejeunea kashyapii and L. mehrana are endemic, earlier reported from Sikkim only. The taxonomic description and illustrations of all are provided in present communication.

Key words: endemic, India, Lejeunea, Meghalaya, new record

\section{INTRODUCTION}

Genus Lejeunea Lib. is one of the largest genera of family Lejeuneaceae with $c a 300$ accepted species in the world (Lee 2013). About 48 species are recorded from different bryogeographical territories in India (Asthana and Sahu 2012, Singh et al., unpubl.). In the present state of our knowledge 13 species viz., Lejeunea aligera Mitt., L. anisophylla Mont., L. cavifolia (Ehrh.) Lindb., L. cocoes Mitt., L. curviloba Steph., L. flava (Sw.) Nees, L. japonica Mitt., L. neelgherriana Gottsche, L. nepalensis Steph., L. obfusca Mitt., L. princeps (Steph.) Mizut., L. subacuta Mitt. and L. tuberculosa Steph. are known from the Meghalaya (Mitten 1861, Mizutani 1971, Singh and Nath 2007, Verma and Rawat 2013). During the course of "Taxonomic studies on Lejeuneaceae Schizostipae, in North-East India", the authors came across with several populations having four unknown Lejeunea species from the Meghalaya. A critical morpho-taxonomic investigations of these specimens and literature review revealed their identity as Lejeunea discreta Lindenb., L. kashyapii M. Dey, D. K. Singh et D. Singh, L. mehrana M. Dey, D. K. Singh et D. Singh and L. parva (S. Hatt.) Mizut. 
These are reported here as new distributional records for the State of Meghalaya. It is interesting to note that Lejeunea kashyapii and L. mehrana are endemic species, earlier reported from Sikkim only. The specimens studied are deposited in the herbarium of the Botanical Survey of India, Eastern Regional Centre, Shillong (ASSAM). The detailed taxonomic description and illustration of each are provided in present communication.

\section{MORPHO-TAXONOMIC DESCRIPTIONS}

\section{Lejeunea discreta Lindenb.}

(Fig. 1)

Lejeunea discreta Lindenb. in Gottsche et al., Syn. Hept. 361 (1845); Mizut., J. Hattori Bot. Lab. 34: 445 (1971); R. L. Zhu and M. L. So, Ann. Bot. Fenn. 36: 224 (1999), same authors, Beih. Nova Hedwigia 121: 144 (2001); S. K. Singh and D. K. Singh, Hep. Anth. Great Himal. Nat. Park H. P., p. 225 (2009); Dey and D. K. Singh, Epiphyll. Liverw. E. Himal., p. 264 (2012); G. E. Lee, Cryptog. Bryol. 34(4): 417 (2013). „ Hygrolejeunea discreta (Lindenb.) Schiffn., Consp. Hepat. Arch. Ind., p. 266 (1898). $\equiv$ Taxilejeunea discreta (Lindenb.) R. M. Schust., Beih. Nova Hedwigia 9: 138 (1963).

= Lejeunea vaginata Steph., Sp. Hepat. 5: 791 (1915).

Plants light green to dull green; shoots $6-15 \mathrm{~mm}$ long, $0.27-0.48 \mathrm{~mm}$ wide; branching irregular, Lejeunea-type; stem cross section subquadrate to oval in outline, $62.5-67.5 \times 47-50 \mu \mathrm{m}, 4-6$ cells across the diameter; cortical cells in a layer of 7(-9) cells, subquadrate to rectangular, 7.5-25 × 7.5-17.5 $\mu \mathrm{m}$, slightly thin walled, medullary cells $6-7$, rectangular to polygonal, 7.5-15 $\times$ $5-12.5 \mu \mathrm{m}$, thin walled. Leaves imbricate to contiguous, widely to obliquely spreading, leaf lobes ovate, $0.19-0.24 \mathrm{~mm}$ long, $0.12-0.16 \mathrm{~mm}$ wide, apex obtuse, curved at apex, margin entire or wavy, antical margin convex, postical margin curved; marginal cells towards apex rectangular to polygonal, 10-17.5 $\times 7.5-15 \mu \mathrm{m}$, median cells polygonal, 15-20 × 12.5-17.5 $\mu \mathrm{m}$, basal cells elongated polygonal, 20-30 × 10-15 $\mu \mathrm{m}$; cells thin walled with small trigones and intermediate thickenings, cuticle smooth; leaf lobule inflated, ovate, $c a 1 / 2$ as long as the lobe, $0.10-0.12 \mathrm{~mm}$ long, $0.07-0.09 \mathrm{~mm}$ wide, bidentate, first tooth unicellular, oblong, second tooth obsolete, hyaline papilla at the proximal side of first tooth; free lateral margin with 4-7 rectangular or linear cells. Underleaves distant, 2-3 times as wide as stem, 0.09-0.13 $\mathrm{mm}$ long, $0.10-0.12 \mathrm{~mm}$ wide, bilobed to $1 / 2$ of its length, lobes triangular, margin entire, sinus acute or subacute. Androecial and gynoecial branches not observed.

Type: Indonesia, Java, "inter L. Thymifolium $\beta$ discretam (Hb. [Nees])" (holotype: STR).

Habitat: Epiphytic, growing on moist and shady places. 

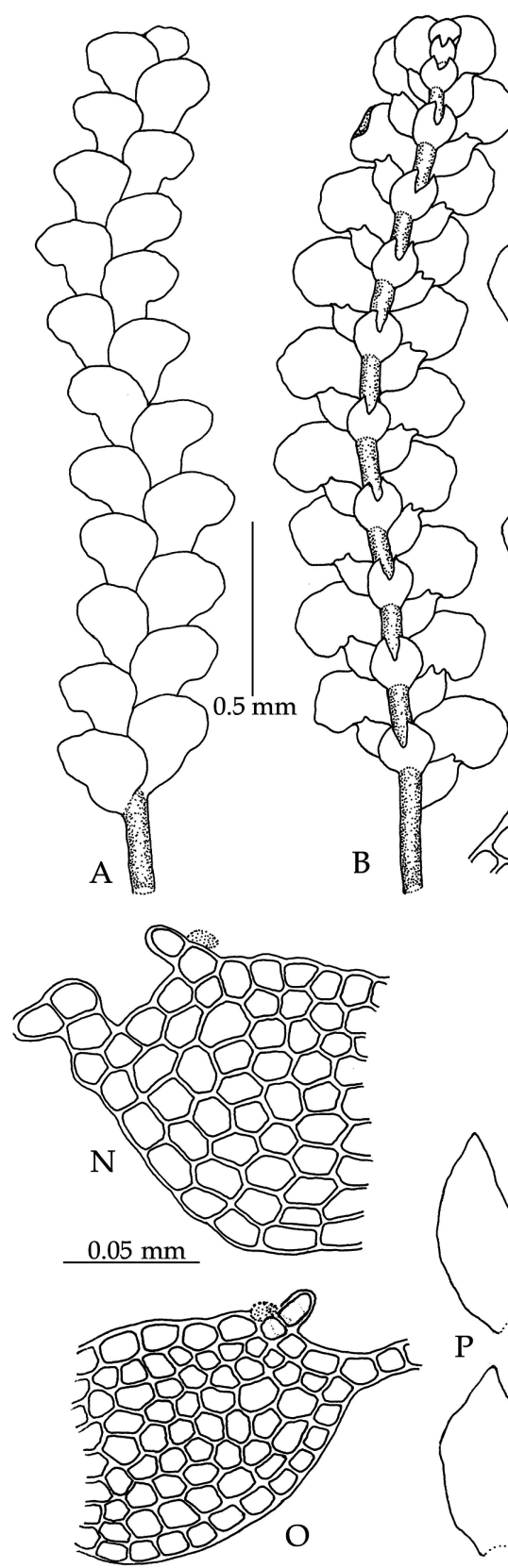

B
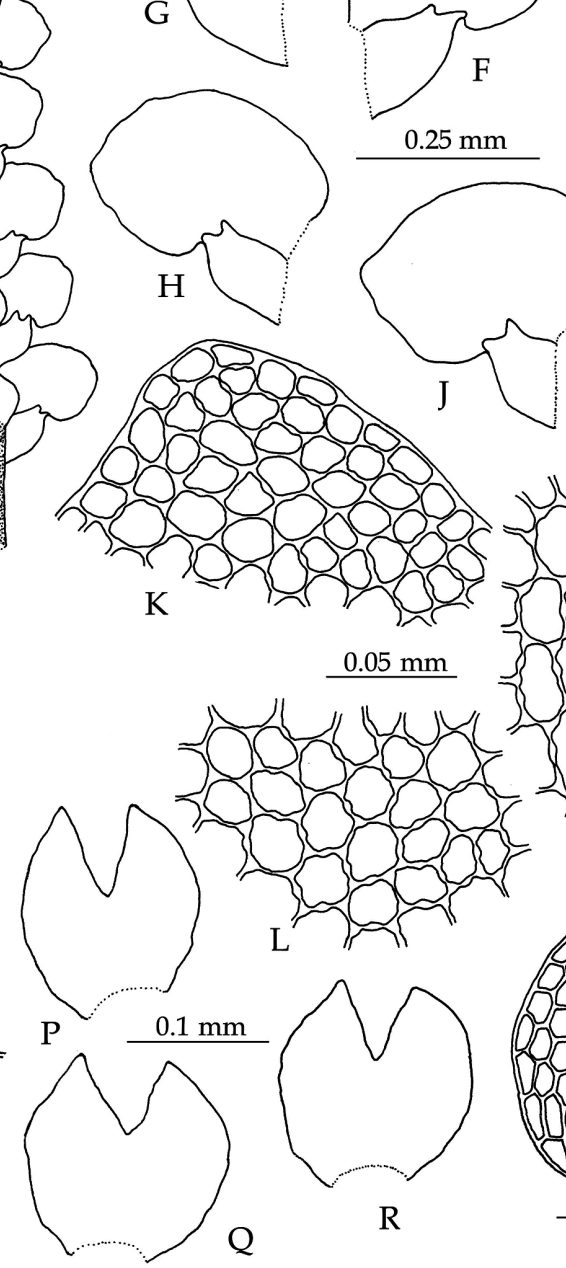
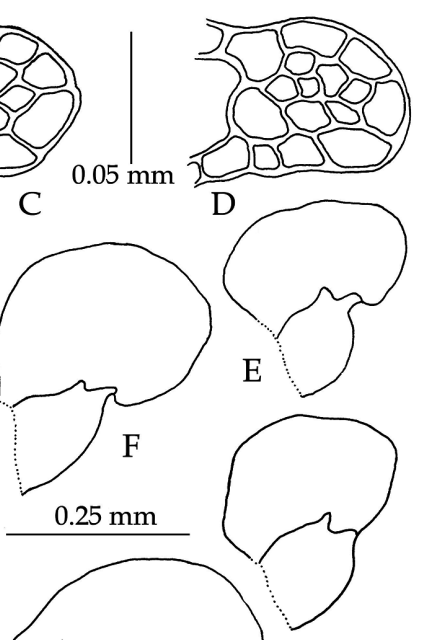

Fig. 1. Lejeunea discreta. $\mathrm{A}=$ a portion of plant in dorsal view; $\mathrm{B}=$ the same in ventral view; $\mathrm{C}-\mathrm{D}=$ transverse sections of stem; $\mathrm{E}-\mathrm{J}=$ leaves; $\mathrm{K}=$ apical leaf cells towards apex; $\mathrm{L}=\mathrm{me}-$ dian leaf cells; $\mathrm{M}$ = basal leaf cells; $\mathrm{N}-\mathrm{O}$ = leaf lobules; $\mathrm{P}-\mathrm{S}=$ underleaves 
Distribution: India: Himachal Pradesh (Singh and Singh 2009), Kerala (Manju et al. 2012); Meghalaya (present study); Sikkim (Dey and Singh 2012); West Bengal (Mizutani 1971). - Bhutan (Long and Grolle 1990). - China (Zhu and So 2001). - Indonesia (Mizutani 1971, Söderström et al. 2010). - Japan (Yamada and Iwatsuki 2006). - Korea (Yamada and Choe 1997). - Malaysia (Chuah-Petiot 2011). - Nepal, New Guinea, New Caledonia (Mizutani 1971). - Philippines (Tan and Engel 1986). - Sri Lanka (Mizutani 1971). - Taiwan (Wang et al. 2011). - Thailand (Lai et al. 2008). - Australia (McCarthy 2006).

Specimen examined: India, Meghalaya, Tuber Sacred Grove, Jaintia Hills, epiphytic, $25^{\circ} 26^{\prime} 11.16^{\prime \prime} \mathrm{N}, 92^{\circ} 16^{\prime} 20.69^{\prime \prime} \mathrm{E}, 1,389 \mathrm{~m}, \mathrm{~S}$. K. Singh \& party, 06.04.2014 (TSLI-14).

Notes: Lejeunea discreta is a distinct species somewhat similar to L. tuberculosa in having oval to suborbicular underleaves, deeply bilobed to $1 / 2$ of its length. But, former differs from the latter in having large ovate lobule which is $c a 1 / 2$ as long as the lobe, small, ovate leaf lobes $0.19-0.24 \mathrm{~mm}$ long, $0.12-$ $0.16 \mathrm{~mm}$ wide which apex are obtuse, margin entire or wavy, antical margin convex, postical margin curved at apex and surface verrucose. Whereas in Lejeunea tuberculosa the leaf lobules are smaller, $1 / 4$ to $1 / 3$ as long as the lobe, leaf lobes are large, ovate to suborbicular (0.14-)0.3-0.47 mm long, (0.10-)0.42 mm wide, apex rounded, margin entire, antical margin convex, postical margin straight or sometimes slightly curved leaf lobes base and leaf surface are punctuate (Dey and Singh 2012).

\section{Lejeunea kashyapii M. Dey, D. K. Singh et D. Singh}

(Fig. 2)

Lejeunea kashyapii M. Dey, D. K. Singh et D. Singh, J. Bryol. 30: 126 (2008); Dey and Singh, Epiphyll. Liverw. E. Himal., p. 277 (2012).

Plant light green when fresh; shoots 8-11 mm long, 1.69-1.87 mm wide; branching irregular, Lejeunea-type; stem cross section subquadrate to oval in outline, 113.1-124.8 × 89.7-97.5 $\mu \mathrm{m}, 6-8$ cells across the diameter; cortical cells in a layer of 7-8(-9) cells, subquadrate to rectangular, (15.6-)31.2-50.7 × (7.8-) 15.6-35.1 $\mu \mathrm{m}$, thin walled, medullary cells $12-16$, rectangular to polygonal, 7.8-19.5 × (3.9-)7.8-15.6 $\mu \mathrm{m}$, thin walled. Leaves imbricate, obliquely spreading, leaf lobes suborbicular, $0.81-0.91 \mathrm{~mm}$ long, $0.69-0.87 \mathrm{~mm}$ wide, apex rounded, margin entire, antical margin convex, postical margin straight or slightly curved; marginal cells towards apex rectangular to polygonal, 23.4-39 $\times 15.6-31.2 \mu \mathrm{m}$, median cells pentagonal to polygonal, $31.2-46.8 \times 23.4-39 \mu \mathrm{m}$, basal cells elongated polygonal, 35.1-62.4 × 27.3-39 $\mu$ m; cells thin walled without trigones and intermediate thickenings, cuticle smooth; oil bodies 16-35 in 


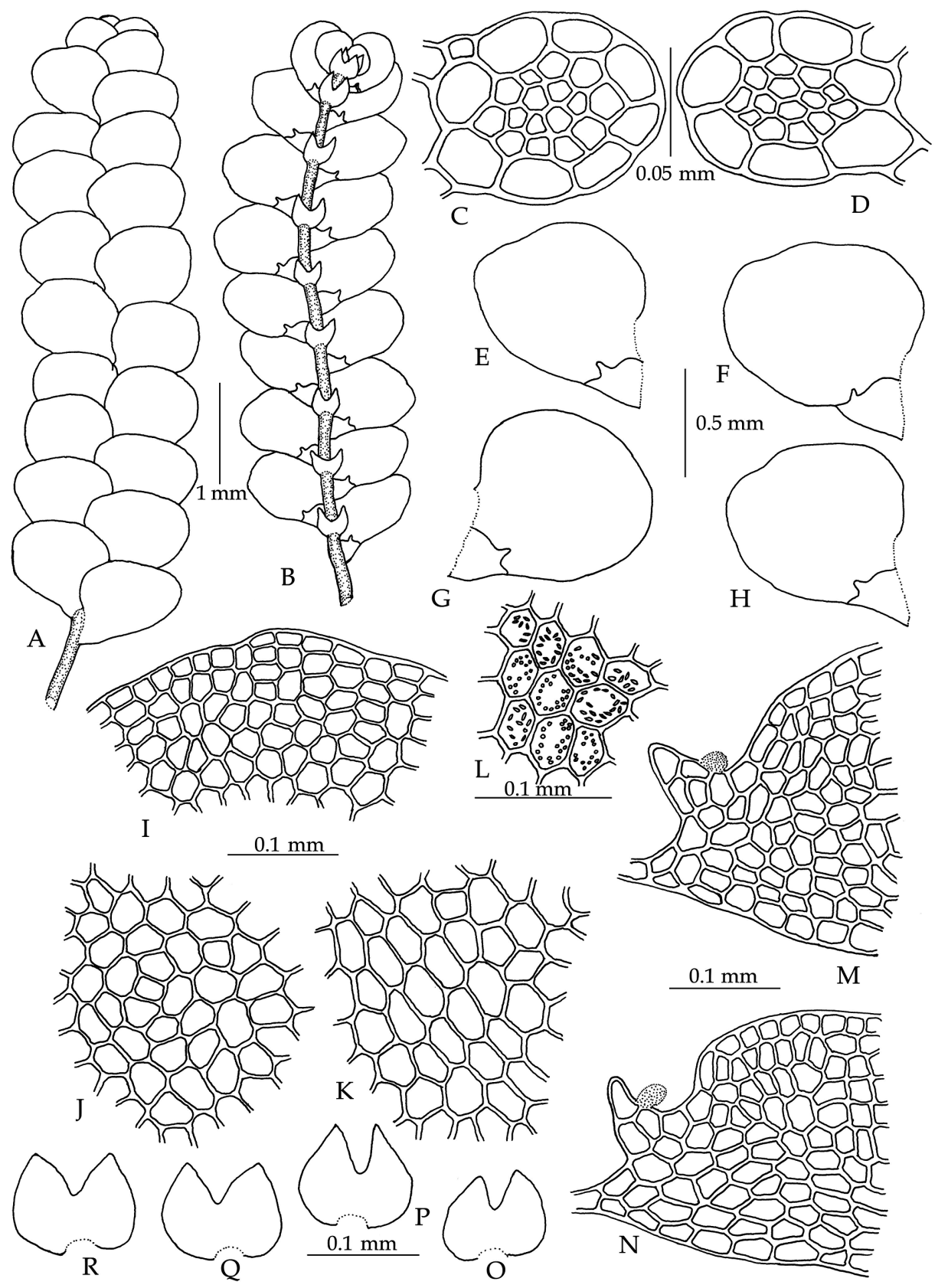

Fig. 2. Lejeunea kashyapii. $\mathrm{A}=$ a portion of plant in dorsal view; $\mathrm{B}=$ the same in ventral view; $\mathrm{C}-\mathrm{D}=$ transverse sections of stem; $\mathrm{E}-\mathrm{H}=$ leaves; $\mathrm{I}=$ apical leaf cells towards apex; $\mathrm{J}=$ median leaf cells; $\mathrm{K}$ = basal leaf cells; $\mathrm{L}=$ leaf cells showing oil bodies; $\mathrm{M}-\mathrm{N}$ = leaf lobule; $\mathrm{O}-\mathrm{R}=$ underleaves 
each cells, elliptical, $5.25-7 \times 3.5 \mu \mathrm{m}$, spherical $3.5 \mu \mathrm{m}$ in diam.; leaf lobule inflated, oblong-ovate-triangular, $1 / 3$ as long as the lobe, $0.23-0.27 \mathrm{~mm}$ long, $0.23-0.27 \mathrm{~mm}$ wide, bidentate, first tooth $2-4$ cells long, $3-4$ cells wide at base, elongated, second tooth obsolete, hyaline papilla at the proximal side of first tooth. Underleaves reniform to suborbicular, distant, 3-4 times as wide as the stem, $0.28-0.37 \mathrm{~mm}$ long, $0.32-0.38 \mathrm{~mm}$ wide, bilobed to $1 / 2-1 / 3$ of its length, sinus acute to obtuse, margin entire, apex acute. Androecial and gynoecial branches not observed.

Type: India, Eastern Himalaya, Sikkim, East district, Pangthang, ca 1,988 m, D. Singh (36482), 05.03.2005 (holotype: CAL).

Habitat: Epiphyllous, growing on shady and moist places.

Distribution: India: Meghalaya (present study), Sikkim (Dey and Singh 2012), endemic.

Specimen examined: India, Meghalaya, Pongtung Village, epiphytic, $25^{\circ} 15^{\prime} 9.9^{\prime \prime} \mathrm{N}$, 91 57' 2.4" E, $744 \mathrm{~m}, \mathrm{~S}$. K. Singh \& party, 09.11.2014 (TSLI-477).

Notes: Lejeunea kashyapii shows affinities with L. anisophylla and L. obscura in general appearance of the plant, size of leaves and leaf lobules, arrangement of underleaves. However, it differs from both the latter species in having elongated first tooth of leaf lobule (up to 3 cells long). Lejeunea anisophylla further differs from L. kashyapii in having ovate leaf lobes with larger trigones and frequent intermediate thickenings, longer than wide underleaves with outer margins bearing a blunt tooth (Dey and Singh 2012). Lejeunea obscura differs from the species in discussion in having robust stem and reduced leaf lobules, leaf lobes with comparatively larger trigones and frequent intermediate thickenings (Dey and Singh 2012).

\section{Lejeunea mehrana M. Dey, D. K. Singh et D. Singh} (Fig. 3)

Lejeunea mehrana M. Dey, D. K. Singh et D. Singh, J. Bryol. 30: 128 (2008); Dey and Singh, Epiphyll. Liverw. E. Himal., p. 282 (2012).

Plant light green; shoots 5-6 mm long, 0.77-0.90 mm wide; branching irregular Lejeunea-type; stem cross section subquadrate to oval in outline, $70-87.5 \times 65-70 \mu \mathrm{m}, 5-8$ cells across the diameter; cortical cells in a layer of 7-8(-9) cells, subquadrate or rectangular, (15-)17.5-30 × (7.5-)10-20 $\mu \mathrm{m}$, thin walled, medullary cells 10-15, polygonal, 10-22.5 × 5-12.5 $\mu \mathrm{m}$, thin walled. Leaves imbricate, obliquely spreading; leaf lobes oblong to ovate, $0.35-0.44$ $\mathrm{mm}$ long, $0.27-0.34 \mathrm{~mm}$ wide, antical margin broad convex, postical margin curved, apex obtuse, margin entire; marginal cells towards apex subquadrate 


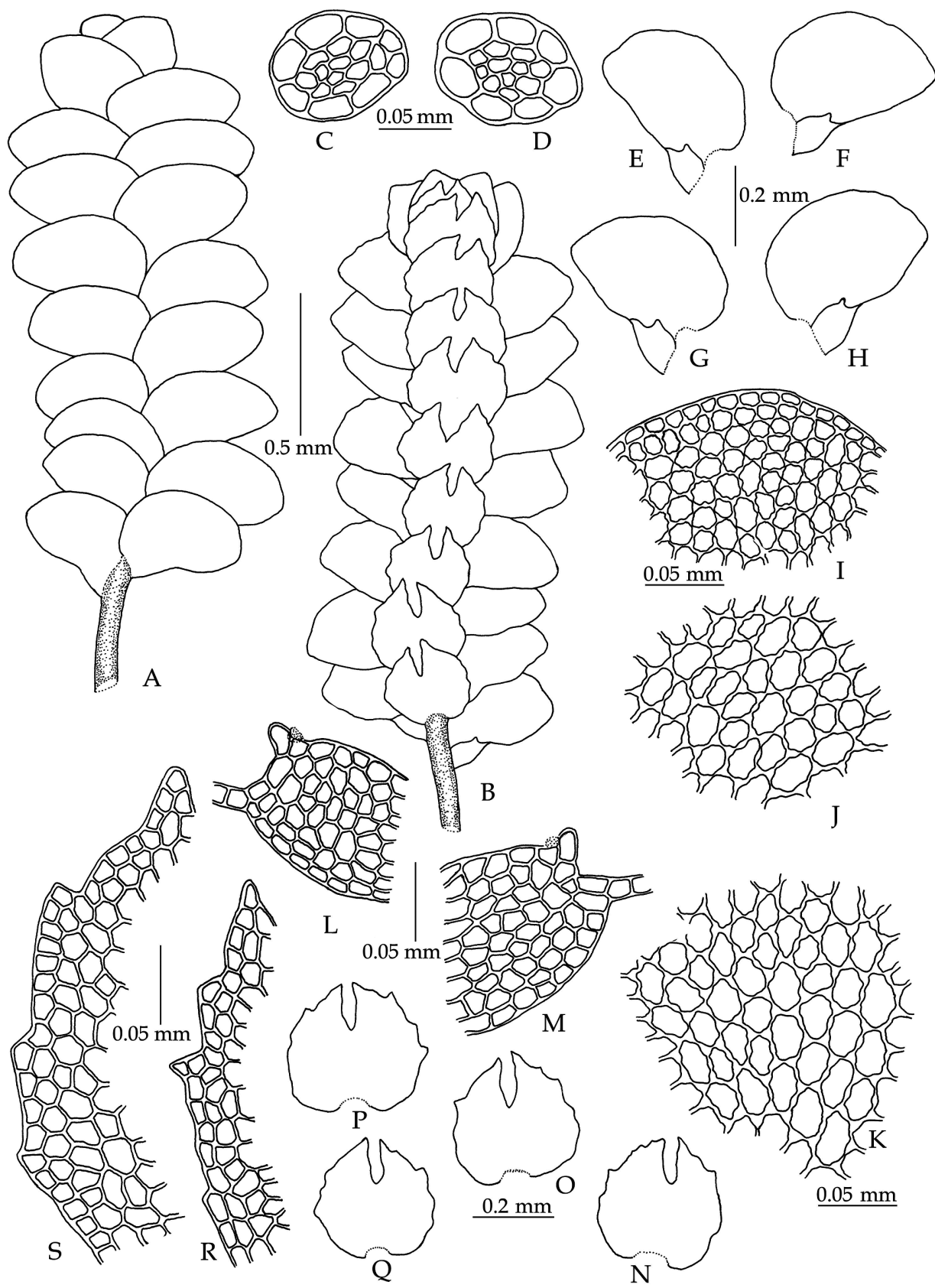

Fig. 3. Lejeunea mehrana. $\mathrm{A}=$ a portion of plant in dorsal view; $\mathrm{B}=$ the same in ventral view; $\mathrm{C}-\mathrm{D}=$ transverse section of stem; $\mathrm{E}-\mathrm{H}=$ leaves; $\mathrm{I}=$ apical leaf cells towards apex; $\mathrm{J}=$ median leaf cells; $\mathrm{K}$ = basal leaf cells; $\mathrm{L}-\mathrm{M}$ = leaf lobules; $\mathrm{N}-\mathrm{Q}$ = underleaves; $\mathrm{R}-\mathrm{S}$ = underleaves marginal cells showing marginal teeth 
or polygonal, $7.5-22.5 \times 5-12.5 \mu \mathrm{m}$, median cells polygonal, $17.5-30 \times 10-17.5$ $\mu \mathrm{m}$, basal cells slightly elongated, hexagonal to polygonal, $22.5-32.5 \times 12.5-20$ $\mu \mathrm{m}$; cells thin walled with subnodular trigones and intermediate thickenings, cuticle smooth; leaf lobule inflated, oblong to ovate, $1 / 3-1 / 4$ as long as the lobe, $0.11-0.13 \mathrm{~mm}$ long, $0.08-0.10 \mathrm{~mm}$ wide, first tooth unicellular with a hyaline papilla on proximal side, second tooth obsolete free lateral margin with 4-6 rectangular or linear cells. Underleaves imbricate, 3-3.5 times as wide as the stem, suborbicular, $0.26-0.31 \mathrm{~mm}$ long, $0.27-0.31 \mathrm{~mm}$ wide, bilobed to $2 / 5-1 / 2$ of its length, outer margin with 1-3 teeth on each lobe, apex acute or subacute, base slightly cordate. Androecial and gynoecial branches not observed.

Type: India, Eastern Himalaya, Sikkim, East district, Ratechhu, ca 1,788 m, D. Singh (36891), 21.02.2006 (holotype: CAL).

Habitat: Epiphytic, growing in moist and shady places in association with Microlejeunea punctiformis.

Distribution: India: Meghalaya (present study), Sikkim (Dey and Singh 2012), endemic.

Specimen examined: India, Meghalaya, Experimental Botanical Garden, Barapani, epiphytic, $25^{\circ} 40^{\prime} 36.46^{\prime \prime}$ N, $91^{\circ} 54^{\prime} 11.45^{\prime \prime}$ E, 986 m, S. K. Singh \& party, 07.11.2014 (TSLI400).

Notes: Lejeunea mehrana can be distinguished by its obliquely spreading imbricate leaves, which is oblong to ovate with obtuse apex, in having suborbicular underleaves with 1-3 blunt teeth at margin. It is closely related to Lejeunea subacuta in habit, leaf shape, size of lobule teeth, shape and position of underleaves. But, the latter differs from the former in having underleaves with entire margin, comparatively delicate stem, leaf cells with small indistinct trigones and without intermediate thickenings (Dey and Singh 2012). Lejeunea mehrana also shows similarity with L. flava, but latter distinctly differs in having leaf lobes with rounded apex and suborbicular to ovate underleaf with entire margin. Our plants slightly different from the type, in having comparatively larger leaf lobules, but in other features it is similar.

\section{Lejeunea parva (S. Hatt.) Mizut.}

(Fig. 4)

Lejeunea parva (S. Hatt.) Mizut., Misc. Bryol. Lichenol. 5: 178 (1971); Lee et al., Cryptog. Bryol. 35(3): 250 (2014). $\equiv$ Microlejeunea rotundistipula Steph. f. parva S. Hatt., Bull. Tokyo Sci. Mus. 11: 123 (1944).

Plant light green; shoots $8-13 \mathrm{~mm}$ long, $0.30-0.36 \mathrm{~mm}$ wide; branching irregular, Lejeunea-type; stem cross section sub quadrate to oval in out- 


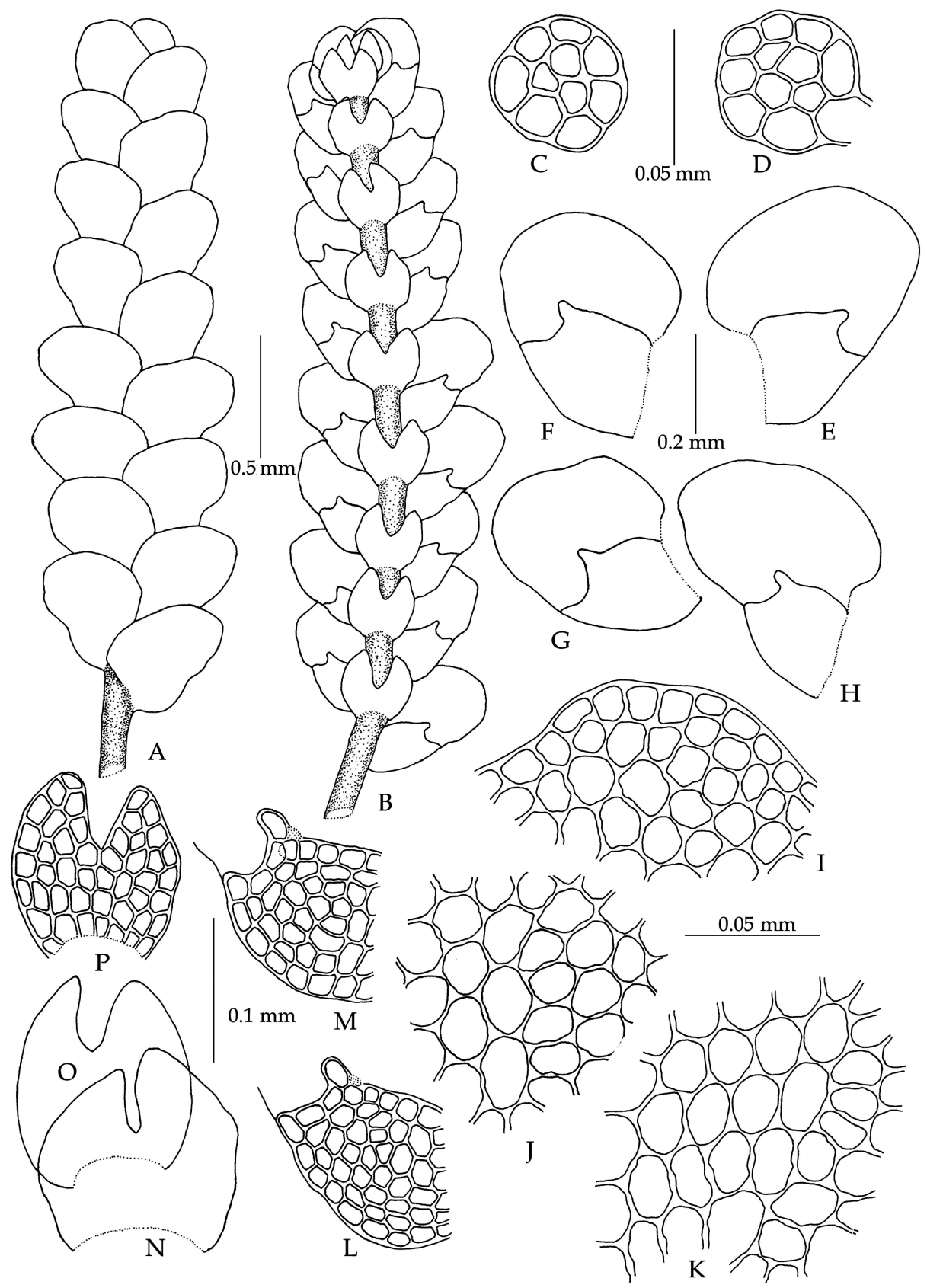

Fig. 4. Lejeunea parva. $\mathrm{A}=$ a portion of plant in dorsal view; $\mathrm{B}=$ the same in ventral view; $\mathrm{C}-\mathrm{D}=$ transverse sections of stem; $\mathrm{E}-\mathrm{H}=$ leaves; $\mathrm{I}=$ apical leaf cells towards apex; $\mathrm{J}=$ median leaf cells; $\mathrm{K}$ = basal leaf cells; $\mathrm{L}-\mathrm{M}=$ leaf lobules; $\mathrm{N}-\mathrm{P}=$ underleaves 
line, 47.5-52.5 $\times 45-50 \mu \mathrm{m}, 4-5$ cells across the diameter; cortical cells in a layer of 7-8 cells, subquadrate or quadrate, $10-20 \times 7.5-15 \mu \mathrm{m}$, slightly thick walled; medullary cells 3-4, subquadrate to polygonal, 7.5-12.5 × 5-10 $\mu \mathrm{m}$, thin walled. Leaves remote or imbricate, suberect to obliquely spreading, leaf lobes ovate, $0.20-0.24 \mathrm{~mm}$ long, $0.16-0.20 \mathrm{~mm}$ wide, apex obtuse to rounded, margin entire, antical margin convex, postical margin straight rarely curved; marginal cells towards apex subquadrate to polygonal, 10-22.5 × 7.5-15(-17.5) $\mu \mathrm{m}$, median cells polygonal, $15-27.5 \times 12.5-17.5 \mu \mathrm{m}$, basal cells slightly elongated hexagonal to polygonal, 15-30 × 10-20 $\mu \mathrm{m}$; cells thick walled, with subnodose trigones and small intermediate thickenings, cuticle punctuate; leaf lobule inflated, $1 / 2-2 / 3$ as long as the lobe, ovate, $0.9-0.10 \mathrm{~mm}$ long, $0.07-0.08$ $\mathrm{mm}$ wide, bidentate, first tooth unicellular, elongated, second tooth obsolete, hyaline papilla at the proximal side of first tooth, free lateral margin with 4-5 subquadrate or linear cells. Underleaves remote, 2-2.5 times as wide as the stem, $0.09-0.10 \mathrm{~mm}$ long, $0.09-0.10 \mathrm{~mm}$ wide, bilobed to $1 / 2-2 / 5$ of its length, lobes triangular, 4 cells long, 4 cells wide at base, apex subacute or rounded. Androecial and gynoecial branches not observed.

Type: Japan, "Prov. Hyuga: Minaminaka-gun, Kitago-mura", Aug. 1939, S. Hattori 2696 (holotype: TNS ?, NICH ?).

Habitat: Epiphytic, growing on moist and shady places.

Distribution: India: Assam (Singh and Barbhuiya 2012), Meghalaya (present study). - China (Zhu and So 2001). - Japan (Yamada and Iwatsuki 2006). - Korea (Yamada and Choe 1997). - Singapore (Piippo et al. 2002). - Thailand (Lee et al. 2014).

Specimen examined: India, Eastern Himalaya, Meghalaya, Experimental Botanical Garden, Barapani, epiphytic, $25^{\circ} 40^{\prime} 36.46^{\prime \prime}$ N, $91^{\circ} 54^{\prime} 11.45^{\prime \prime}$ E, 986 m, S. K. Singh \& party, 07.11.2014 (TSLI-423).

Notes: Lejeunea parva is a tiny and little known species in Indian bryology. It shows similarity with Lejeunea tuberculosa in leaf lobules and underleaf shapes. But latter differs in having comparatively robust stem with 8-12 medullary cells, leaf lobule $c a 1 / 3$ as long as the lobe (Zhu and So 2001). Whereas Lejeunea parva has delicate stem with 3-4 medullary cells, leaf lobes directed forward, lobule is relatively larger, $1 / 2-2 / 3$ as long as the lobe and underleaves bilobed up to $2 / 5-1 / 2$ of its length. Our plant slightly differs from the description and illustration of Chinese plants by Zhu and So (2001) in stem anatomy and shape of leaves but matching with Thai illustration by Lee et al. (2014). 
Acknowledgements - The authors are grateful to Director, BSI, Kolkata and Head of Office, Eastern Regional Centre, Botanical Survey of India, Eastern Regional Centre, Shillong for facilities and encouragements.

\section{REFERENCES}

Asthana, A. K. and Sahu, V. (2012): Current status of genus Lejeunea Libert. in India. - Ann. Forrest. 20(1): 67-73.

Chuah-Petiot, M. S. (2011): A checklist of Hepaticae and Anthocerotae of Malaysia. - Polish Bot. J. 56: 1-44.

Dey, M. and Singh, D. K. (2012): Epiphyllous liverworts of Eastern Himalaya. - Botanical Survey of India, Kolkata.

Lai, M. J., Zhu, R. L. and Chantanaorrapint, S. (2008): Liverworts and hornworts of Thailand: an updated checklist and bryofloristic accounts. - Ann. Bot. Fenn. 45: 321-341. http://dx.doi.org/10.5735/085.045.0501

Lee, G. E. (2013): A systematic revision of the genus Lejeunea Lib. (Marchantiophyta: Lejeuneaceae) in Malaysia. - Cryptog. Bryol. 34(4): 381-484. http://dx.doi.org/10.7872/ cryb.v34.iss4.2013.381

Lee, G. E., Pócs, T., Chantanaorrapint, S., Damanhuri, A. and Latiff, A. (2014): An account of the genus Lejeunea (Marchantiophyta: Lejeuneaceae) in Thailand, including seven newly recorded species. - Cryptog. Bryol. 35(3): 247-259. http://dx.doi.org/10.7872/ cryb.v35.iss3.2014.247

Long, D. G. and Grolle, R. (1990): Hepaticae of Bhutan II. - J. Hattori Bot. Lab. 68: 381-440.

Manju, C. N., Pócs, T., Rajesh, K. P. and Prakashkumar, R. (2012): Lejeuneaceae (Marchantiophyta) of the Western Ghats, India. - Acta Biol. Plant. Agriensis 2: 127-147.

McCarthy, P. M. (2006): Checklist of Australian liverworts and hornworts. Australian Biological Resources Study, Canberra. Version 6 April 2006. - http://www.anbg.gov.au/abrs/ liverwortlist/liverworts_intro.html

Mitten, W. (1861): Hepaticae Indiae Orientalis, an enumeration of the Hepaticae of East Indies. - J. Proc. Linn. Soc. Bot. 5: 89-128.

Mizutani, M. (1971): Lejeunea from the Himalayan region. - J. Hattori Bot. Lab. 34: 445-457.

Piippo, S., He, X. L., Juslén, A., Tan, B. C., Murphy, D. H. and Pócs, T. (2002): Hepatic and hornwort flora of Singapore. - Ann. Bot. Fenn. 39: 101-128.

Singh, A. P. and Nath, V. (2007): Hepaticae of Khasi and Jaintia Hills: Eastern Himalayas. Bishen Singh Mahandrapal Singh, Dehra Dun, 382 pp.

Singh, S. K. and Barbhuiya, H. A. (2012): Compendium to Marchantiophyta and Anthocerotophyta of Assam, India. - Arch. Bryol. 149: 1-30.

Singh, S. K. and Singh, D. K. (2009): Hepaticae and Anthocerotae of Great Himalayan National Park and its environs (H. P.), India. - Botanical Survey of India, Kolkata.

Söderström, L., Gradstein, S. R. and Hagborg, A. (2010): Checklist of the hornworts and liverworts of Java. - Phytotaxa 9: 53-149. http://dx.doi.org/10.11646/phytotaxa.9.1.7

Tan, B. C. and Engel, J. J. (1986): An annotated checklist of Philippine Hepaticae. - J. Hattori Bot. Lab. 60: 283-355. 
Verma, P. K. and Rawat, K. K. (2013): Lejeunea srivastavae sp. nov. (Marchantiophyta: Lejeuneaceae), from Nilgiri Hills of Western Ghats (India). - Taiwania 58(1): 7-11.

Wang, J., Lai, M. J. and Zhu, R. L. (2011): Liverworts and hornworts of Taiwan: an updated checklist and floristic accounts. - Ann. Bot. Fenn. 48: 369-395. http://dx.doi. org $/ 10.5735 / 085.048 .0501$

Yamada, K. and Choe, D. M. (1997): A checklist of Hepaticae and Anthocerotae in the Korean peninsula. - J. Hattori Bot. Lab. 81: 281-306.

Yamada, K. and Iwatsuki, Z. (2006): Catalogue of the hepatics of Japan. - J. Hattori Bot. Lab. 99: 1-106.

Zhu, R. L. and So, M. L. (2001): Epiphyllous liverworts of China. - Beih. Nova Hedwigia 121: $1-418$. 